\title{
unindra
}

Universitas Indraprasta PGRI

Address: Jl. Nangka No. 58 C (TB. Simatupang), Kel. Tanjung Barat, Kec. Jagakarsa, Jakarta Selatan 12530, Indonesia.

-62 (021) 7818718 - 78835283; url: www.unindra.ac.id; 耘 psyclrev@unindra.ac.id

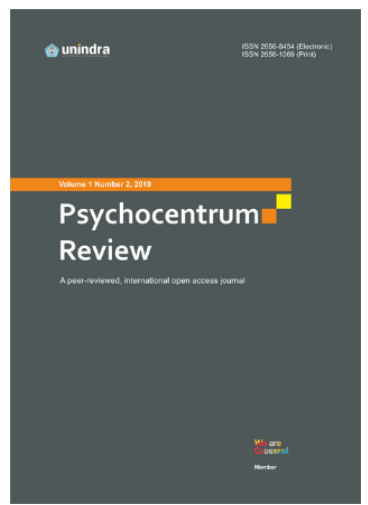

\section{Psychocentrum Review}

ISSN 2656-8454 (Electronic)| ISSN 2656-1069 (Print)

Editor: (iD) Hayu Stevan

Publication details, including author guidelines

URL: http://journal.unindra.ac.id/index.php/pcr/about/submissions\#authorGuidelines

\section{Penyesuaian Diri Akademik Mahasiswa Ditinjau Dari Regulasi Emosi Dan Self-Esteem}

Feny Mandoa', Habel Saud², Yansen Alberth Reba ${ }^{3}$

Universitas Cenderawasih, Jayapura

\section{Article History \\ Received : 08 Maret 2021 \\ Revised : 27 Maret 2021 \\ Accepted : 28 Maret 202}

How to cite this article (APA $6^{\text {th }}$ )

Mandoa, F., Saud, H., \& Reba, Y. A. (2021). Penyesuaian Diri Akademik Mahasiswa Ditinjau dari Regulasi Emosi dan Self-Esteem. Psychocentrum Review, 3(1), 119-127. DOI: 10.26539/pcr.31595

The readers can link to article via https://doi.org/10.26539/pcr.31595

Correspondence regarding this article should be addressed to:

Feny Mandoa, Fakultas Keguruan dan IImu Pendidikan, Universitas Cenderawasih, Jayapura, Indonesia, E-mail: fenymandoa02@gmail.com

SCROLL DOWN TO READ THIS ARTICLE

Universitas Indraprasta PGRI (as Publisher) makes every effort to ensure the accuracy of all the information (the "Content") contained in the publications. However, we make no representations or warranties whatsoever as to the accuracy, completeness, or suitability for any purpose of the Content. Any opinions and views expressed in this publication are the opinions and views of the authors, and are not the views of or endorsed by Universitas Indraprasta PGRI. The accuracy of the Content should not be relied upon and should be independently verified with primary sources of information.

\section{(c) (1) (\$)}

This work is licensed under a Creative Commons Attribution-NonCommercial 4.0 International License.

Copyright by Mandoa, F., Saud, H., \& Reba, Y. A. (2021)

The authors whose names are listed in this manuscript declared that they have NO affiliations with or involvement in any organization or entity with any financial interest (such as honoraria; educational grants; participation in speakers' bureaus; membership, employment, consultancies, stock ownership, or other equity interest; and expert testimony or patent-licensing arrangements), or non-financial interest (such as personal or professional relationships, affiliations, knowledge or beliefs) in the subject matte or materials discussed in this manuscript. This statement is signed by all the authors to indicate agreement that the all information in this article is true and correct. 


\title{
Penyesuaian Diri Akademik Mahasiswa Ditinjau Dari Regulasi Emosi Dan Self-Esteem
}

\author{
Feny Mandoa1*, Habel Saud², Yansen Alberth Reba ${ }^{3}$ \\ Fakultas Keguruan dan Ilmu Pendidikan, Universitas Cenderawasih, Jayapura
}

\begin{abstract}
This study aims to analyze the effect of Emotional Regulation and Self-Esteem on Academic Self-Adjustment. The method used is quantitative correlational. This research was conducted in the counseling study program in January-February 2021. The population of this study were students of the Guidance and Counseling Study Program at Cenderawasih University Class of 2016,2017,2018,2019 and 2020 with a total of 115 students. Based on the Slovin formula, 89 samples were obtained using the Proportionate Stratified technique. Random Sampling. The data collection technique used an emotional regulation questionnaire, a self-esteem questionnaire and an academic adjustment questionnaire with a Likert scale assessment. This study uses simple and multiple regression data analysis. The results of this study indicate that: there is an effect of emotional regulation on academic self-adjustment with the results of $\mathrm{R} 2=38.9 \%$ and the effect of self-esteem on academic self-adjustment with the results of R2 $=62.6 \%$. There is an effect of emotional regulation and Self-Esteem on academic self-adjustment, with the result of $\mathrm{R} 2=69.3 \%$, while the remaining $30.7 \%$ is influenced by other variables outside of this study.
\end{abstract}

Keywords: Regulasi Emosi, Self-Esteem, Penyesuaian Diri Akademik.

Corresponding author: Feny Mandoa, Universitas Cenderawasih, Kampus Abepura Jl. Raya Sentani, Jayapura, 99351, Indonesia; E-mail: fenymandoa02@ gmail.com

\section{Pendahuluan}

Pendidikan adalah salah satu faktor dalam kemajuannya suatu bangsa. Maka dari itu diharapkan melalui pendidikan dapat tercipta sumber daya manusia yang kompeten dan mempunyai kemampuan serta daya saing yang kuat. Melalui UU SISDIKNAS No. 20 Tahun 2003 pada pasal 3 yang menyatakan bahwa pendidikan dilaksanakan dalam rangka untuk membentuk manusia yang dapat mengembangkan potensi dan kemampuan agar dapat berguna bagi dirinya, masyarakat, bangsa dan Negara, selanjutnya dalam pasal 14 menerangkan jika jenjang pendidikan terbagi menjadi 3 yaitu jenjang pendidikan pra sekolah, pendidikan dasar, pendidikan menengah dan pendidikan tinggi. Jenjang pendidikan tinggi dapat dilaksanakan setelah pendidikan menengah dengan program-program berupa diploma, sarjana, magister, doktor dan spesialis.

Universitas Cenderawasih (UNCEN) adalah PTN pertama dan tertua di Papua, disahkan pada tanggal 10 November 1962. Sebagai PTN di Provinsi Papua, UNCEN mempunyai 9 Fakultas dan program Pascasarjana dengan 51 Program Studi dan 21 Program studi pada Pascasarjana. Salah satu program Studi yang ada di UNCEN adalah Program Studi Bimbingan dan Konseling (BK) yang berada di dalam Fakultas Keguruan dan Ilmu Pendidikan (FKIP). Program Studi Bimbingan Konseling (BK) adalah program studi yang mempersiapkan calon- 
calon guru-guru BK yang handal dalam memberikan bimbingan sekaligus konseling bagi siswa/siswi di sekolah.

Mahasiswa Program Studi BK tentu saja tidak akan lepas dari perbedaan latar belakang budaya dan asal tempat. Dengan berlatar belakang budaya dan asal tempat yang berbeda, tentu pasti akan ada perbedaan dalam berpendapat, cara berkomunikasi, dan bahkan dalam pergaulan. Maka dari itu mahasiswa diharapkan agar dapat beradaptasi atau menyesuaikan diri dengan lingkungan kampus agar ia dapat menyelesaikan tugas-tugasnya baik dalam bidang akademik maupun non akademik (Patawari, 2020) .

Keadaan yang terus berubah-ubah maka dibutuhkan kemampuan untuk penyesuaian diri agar tetap mengikuti keadaan ataupun dapat beradaptasi dengan baik pada lingkungan, terlebih lagi pada bidang akademiknya (Br Sembring \& Lim, 2020). Hasilnya, mahasiswa yang dapat beradaptasi dengan baik dibidang akademiknya akan mendapat hasil yang memuaskan. Hal ini dibuktikan dengan penelitian yang dilakukan oleh Fitri \& Kustanti (2018) bahwa terdapat hubungan yang substansial antara penyesuaian diri akademik dengan prestasi belajar. Semakin baik penyesuaian diri akademiknya maka hasilnya juga akan tinggi dan begitu pun kebalikannya.

Maka dari itu dibutuhkan kemampuan untuk percaya pada diri sendiri jika ia dapat melakukan penyesuaian diri akademik dengan baik. Self-esteem adalah penilaian terhadap diri pribadi individu yang diwujudkan melalui perilaku yang ditunjukannya (Khairat \& Adiyanti, 2016) Melalui penelitian yang dilakukan oleh Sakina (Sakinah, 2017) salah satu factor penyesuaian akademik yang paling besar adalah self-esteem sebesar $17,5 \%$. Selain selfesteem, regulasi emosi juga turut menjadi salah satu factor yang mempengaruhi penyesuaian diri akademik (Sakinah, 2017). Regulasi emosi atau biasa disebut mengontrol emosi adalah cara seseorang dalam membangun emosi dan mengetahui dengan cara apa untuk menyampaikan emosinya (Gross \& Jhon, 2003). Agar mahasiswa Prodi Bimbingan Konseling dapat menyesuaikan dirinya dengan lingkungannya ia harus dapat mengontrol emosinya, baik itu dalam kegiatan kesehariannya terutama dalam kehidupan akademiknya.

Penelitian yang dilakukan oleh Saniskoro \& Akmal (2017) menyatakan, penyesuaian diri mempunyai peran sebesar $17 \%$ terhadap stress akademik. Berdasarkan hasil dari penelitian yang dilakukan Saniskoro \& Akmal (2017) menunjukan bahwa jika mahasiswa tidak dapat menyesuaian dirinya dengan baik pada lingkungan kampus, maka kesulitan-kesulitan akan ia alami khususnya dalam bidang akademiknya serta penelitian yang dilakukan oleh Fanani \& Jainurakhma (2020) menunjukan adanya variasi penyesuaian diri yang dilakukan oleh mahasiswa dalam pembelajaran daring selama masa pandemi Covid-19. Dalam penelitian ini bertujuan untuk mencari tau ada atau tidak adanya pengaruh regulasi emosi dan self-esteem terhadap penyesuaian diri mahasiswa Bimbingan dan Konseling Universitas Cenderawasih.

\section{Metode}

Metode penelitian yang digunakan didalam penelitian ini adalah deskriptif korelational untuk melihat pengaruh Regulasi Emosi (X1) dan Self-Esteem (X2) terhadap Penyesuaian Diri Akademik (Y). Pelaksanaan penelitian bertempat di Universitas Cederawasih Jayapura Fakultas Keguruan dan Ilmu Pendidikan (FKIP) Jurusan Ilmu Pendidikan (JIP), terlebih khusus Program Bimbingan dan Konseling yang bertempat di Jalan Raya Sentani Jayapura, Papua. Waktu pelaksanaan penelitian dilakukan pada bulan Februari 2021. 


\section{Partisipan}

Populasi dalam penelitian ini adalah mahasiswa Universitas Cenderawasih Fakultas Keguruan dan Ilmu Pendidikan (FKIP) Program Studi Bimbingan dan Konseling angkatan, 2016, 2017, 2018, 2019 dan 2020 dengan jumlah 115 mahasiswa

\section{Prosedur Sampling}

- Teknik dalam menentukan sampel dengan menggunakan rumus Slovin hasilnya didapat 89 mahasiswa yang menjadi sampel, serta untuk mengambil sampel setiap angkatan menggunakan rumus proportionate stratified random sampling.

Tabel 1. Jumlah Sampel Perangkatan

\begin{tabular}{cccc}
\hline No. & Tahun Angkatan & Jumlah Populasi Mahasiswa & Jumlah Sampel Perangkatan \\
\hline 1. & 2016 & 24 & 19 \\
2. & 2017 & 29 & 22 \\
3. & 2018 & 21 & 16 \\
4. & 2019 & 18 & 14 \\
5. & 2020 & 23 & 18 \\
\multicolumn{2}{l}{ Total Sampel } & & 89 \\
\hline
\end{tabular}

\section{Bahan dan Peralatan}

Teknik pengumpulan data yang dipergunakan dalam penelitian ini adalah kuisioner atau angket. Kuisioner yang digunakan dalam penelitian ini adalah kuisioner atau angket regulasi emosi, kuisoner Self-Esteem dan kuisioner penyesuaian diri akademik. Didalam kuisioner penyesuaian diri akademik menggunakan teori Schneider (1964) dengan aspekaspek 1) Kontrol terhadap emosi yang berlebihan, 2) Mekanisme pertahanan diri yang minimal, 3) Frustasi personal yang minimal, 3) Pertimbangan rasional dan kemampuan mengarahkan diri, 5) Kemampuan untuk belajar dan memanfaatkan pengalaman masa lalu, 6) Sikap realistis dan objektif. Kuisioner Self-Esteem disusun berdasarkan aspekaspek dari Coopersmith (1967) yaitu: 1) Power, 2) Significancance, 3) Virtue, 4) Competence. Kuisoner regulasi emosi disusun berdasarkan aspek-aspek dari (Goleman, 2015) yaitu: 1) Strategies, 2) Goals, 3) Impulse, 4) Acceptance. Kuisioner tersebut berisi pertanyaan-pertanyaan sebagai penggerak bagi indicator kebiasaan agar diperoleh jabatan yang menjadi cerminan pada keadaan subjek. Dalam penelitian ini menggunakan angket dengan skor berdasarkan skala Likert. Kuisioner ini disusun sendiri dan sudah melalui uji pakar. Sebelum melakukan uji validitas isi oleh pakar terdapat 16 butir pernyataan regulasi emosi, 16 butir pernyataan kuisioner self-esteem dan 32 butir pernyataan kuisioner penyesuaian diri akademik, sesudah dilakukan uji validitas isi menjadi 32 butir pernyataan kuisoner regulasi emosi, 32 butir pernyataan self-esteem dan 39 butir pernyataan kuisioner penyesuaian diri akademik.

\section{Prosedur}

Uji prasayarat berupa uji normalitas dengan hasil nilai signifikansi variabel regulasi emosi $=0,361>0,05$, nilai siginifikansi variabel self-esteem $=0,851>0,05$ dan variabel penyesuaian diri akademik $=0,101>0,05$. Nilai sig. Ketiga variabel tersebut lebih besar dari 0,05 maka data dikatakan nilai berdistribusi normal, berikutnya uji Linearitas dengan hasil nilai sig. sebesar 0,284 yang mana lebih besar dari nilai 0,05, maka dikatakan bahwa terdapat hubungan yang linear secara signifikan antara variabel bebas regulasi emosi (X1) dan variabel terikat penyesuaian diri akademik (Y) dan nilai sig. sebesar 
0,329 yang mana lebih besar dari nilai 0,05. hubungan yang linear secara signifikan antara variabel bebas self-esteem (X) dan variabel terikat penyesuaian diri akademik (Y), selanjutnya yaitu uji Hetereroskidastisitas dengan hasil variabel self-esteem dengan nilai sig. 0,251 > 0,05 dan variabel regulasi emosi dengan nilai sig. $0.70>0,05$, maka dari data tersebut dapat dikatan tidak terjadi uji heteroskidastisitas dalam model regresi. Selanjutnya uji multikolinearitas dengan hasil variabel self-esteem mempunyai nilai tolerance sebesar $0,987>0,05$ dan nilai VIF 1,014 < 10 dan variabel regulasi emosi mempunyai nilai tolerance sebesar 0,987 > 0,05 dan nilai VIF $1.014<10$. Sehingga dapat dikatakan tidak terjadi multikolinearisme dalam model regresi.

\section{Analisis Data}

Untuk mengetahui pengaruh antara variabel dilakukan uji regresi untuk menguji signifikansi pengaruh per variabel (Sugiyono, 2017). Uji hipotesis akan memakai teknik regresi sederhana dan regresi linear berganda dikarenakan penelitian ini dibuat untuk mencari pengaruh ketiga variabelnya. Seluruh proses pengujian data didalam penelitian ini akan diuji dengan memakai perangkat aplikasi SPSS 20 for windows. Hipotesis penelitian sebagai berikut : 1) Ada pengaruh regulasi emosi terhadap penyesuaian diri akademik mahasiswa, 2) ada pengaruh self-esteem terhadap penyesuaian diri akademik mahasiswa, 3) Adakah pengaruh regulasi emosi dan self-esteem terhadap penyesuaian diri akademik mahasiswa?.

\section{Hasil}

Untuk mengetahui adanya pengaruh Regulasi Emosi (X1) terhadap Penyesuaian Diri Akademik (Y) dalam analisis regresi linear sederhana, dapat dilihat pada nilai R Square atau R2 yang terdapat pada output SPSS bagian output Tabel 2. Model Summary:

Tabel 2. Model Summary

\begin{tabular}{ccccc}
\hline \multicolumn{5}{c}{ Model Summary } \\
\hline Model & $\mathrm{R}$ & $\mathrm{R}$ Square & Adjusted R Square & Std. Error of the Estimate \\
1 & $.624^{\mathrm{a}}$ & .389 & .382 & 14.904 \\
a. Predictors: (Constant), Regulasi Emosi & & \\
\hline
\end{tabular}

Dari Tabel 2. Model Summary di atas diketahui nilai R Square sebesar 0,389. Nilai ini mengandung arti bahwa pengaruh Regulasi Emosi (X1) terhadap Penyesuaian Diri Akademik (Y) adalah sebesar 38,9 \% sedangkan 61,1 \% Penyesuaian Diri Akademik dipengaruhi oleh variabel lain yang tidak diteliti.

Untuk mengetahui seberapa besar pengaruh Self-Esteem (X2) terhadap Penyesuaian Diri Akademik (Y) dalam analisis regresi linear sederhana, dapat dilihat pada nilai R Square atau R2 yang terdapat pada output SPSS bagian output Tabel 3. Model Summary

Tabel 3. Model Summary

\begin{tabular}{ccccc}
\hline \multicolumn{4}{c}{ Model Summary } \\
\hline Model & $\mathrm{R}$ & $\mathrm{R}$ Square & Adjusted R Square & Std. Error of the Estimate \\
1 & $.791^{\mathrm{a}}$ & .626 & .622 & 11.654 \\
a. Predictors: (Constant), Self-Esteem & & & \\
\hline
\end{tabular}

Dari Tabel 3. Model Summary di atas diketahui nilai R Square sebesar 0,626. Nilai ini mengandung arti bahwa pengaruh Self-Esteem (X2) terhadap Penyesuaian Diri Akademik 
Mahasiswa (Y) adalah sebesar 62,6 \% sedangkan 37,4 \% Penyesuaian Diri Akademik Mahasiswa dipengaruhi oleh variabel lain yang tidak diteliti.

Untuk mengetahui seberapa besar pengaruh Regulasi Emosi (X1) dan Self-Esteem (X2) terhadap Penyesuaian Diri Akademik (Y) dalam analisis regresi linear berganda, dapat dilihat pada nilai R square atau R2 yang terdapat pada output SPSS bagian Tabel 4. Model Summary

Tabel 4. Model Summary

\begin{tabular}{|c|c|c|c|c|}
\hline \multicolumn{5}{|c|}{ Model Summary } \\
\hline Model & $\mathrm{R}$ & R Square & Adjusted R Square & Std. Error of the Estimate \\
\hline 1 & $.832^{\mathrm{a}}$ & .693 & .686 & 10.672 \\
\hline \multicolumn{5}{|c|}{ a. Predictors: (Constant), SE, RE } \\
\hline
\end{tabular}

Dari Tabel 4. Model Summary di atas diketahui nilai R Square sebesar 0,693. Nilai ini mengandung arti bahwa pengaruh Regulasi Emosi (X1) dan Self-Esteem (X2) terhadap Penyesuaian Diri Akademik (Y) adalah sebesar 68,3 \% sedangkan 30,7 \% Penyesuaian Diri Akademik dipengaruhi oleh variabel lain yang tidak diteliti..

\section{Pembahasan}

\section{Pengaruh Regulasi Emosi Terhadap Penyesuaian Diri Akademik}

Berdasarkan hasil penelitian ini, ditemukan terdapat pengaruh regulasi emosi mempunyai pengaruh positif terhadap penyesuaian diri akademik pada mahasiswa, dimana variabel pada regulasi emosi mempunyai pengaruh sebesar $38,9 \%$. Hal ini menunjukan bahwa semakin tinggi variabel regulasi emosi maka semakin tinggi penyesuaian diri akademik pada mahasiswa. Hal ini sejalan dengan hasil penelitian yang ditemukan (Widuri, 2012) menunjukkan bahwa dengan mengaplikasikan regulasi emosi dalam kehidupan akan berdampak positif baik dalam kesehatan fisik, keberhasilan akademik, dan kemudahan dalam membina hubungan dengan orang lain. Kemampuan meregulasi emosi menyebabkan individu memiliki keyakinan pada diri sendiri dan kemampuan diri atau dengan kata lain kemampuan untuk bergantung pada diri sendiri dan menyadari kekuatan serta keterbatasan diri.

Regulasi emosi yang dimaksud fokus pada kemampuan individu dalam penyesuaian diri, mengatur dan mengekspresikan emosi dan perasaan dalam kehidupan sehari-hari melalui sikap dan perilakunya, seperti proses dalam beradaptasi dan merespon terhadap lingkungan sosial di sekitarnya (Anggraini \& Desiningrum, 2018). Widuri (2012) menyatakan bahwa regulasi emosi menekankan pada bagaimana dan mengapa emosi itu sendiri mampu mengatur dan memfasilitasi proses-proses psikologis, seperti memusatkan perhatian, pemecahan masalah, dukungan sosial. Individu yang memiliki kesulitan dalam regulasi emosi sulit untuk beradaptasi, menjalin relasi dengan orang lain dan mempertahankan hubungan yang telah terjalin dengan orang lain.Individu harus dapat mengekspresikan emosinya dengan wajar dan tepat serta tidak berlarut-larut. Individu yang memiliki kesulitan untuk meregulasi emosi cenderung untuk terjebak dalam emosinya dan pada akhirnya sulit untuk membuat keputusan dengan tepat, menghadapi permasalahan dalam hidupnya dengan positif, serta tidak terbuka pada pengalaman baru (Anggreiny \& Sulistyaningsih, 2013). Individu yang memiliki kontrol impuls yang tinggi akan memiliki regulasi emosi yang tinggi pula. Ketika seseorang tidak mampu mengkontrol impuls, ia akan menerima belief yang pertama kali muncul pada dirinya tanpa mempertimbangkan hal lainnya. Akibatnya ia akan percaya setiap kejadian negatif dan berlaku sesuai dengan belief-nya, maka Tarigan (2018) menyimpulkan jika individu yang memiliki kontrol impuls dapat menahan dan mengevaluasi kejadian negatif yang menimpanya dan berpikir secara rasional. Ia tidak akan terjebak dan menerima kejadian negatif secara cuma-cuma. 
Menurut Anggraini \& Desiningrum (2018) Orang yang memiliki tingkat regulasi emosi yang rendah memiliki kepribadian neuroticism dengan ciri-ciri sensitif, moody, suka gelisah, sering merasa cemas, panik, harga diri rendah, kurang dapat mengontrol diri dan tidak memiliki kemampuan coping yang efektif terhadap stress. Yusuf \& Kristiana (2017) berpendapat bahwa kemampuan dalam meregulasi emosi akan membuat individu terhindar dari hal-hal yang mungkin membuat individu tersebut dalam kesulitan bila tidak dapat mengelola emosinya karena munculnya dampak negatif dari perilaku yang muncul akibat ketidakmampuan dalam mengendalikan impuls emosi. Dengan kata lain, jika individu memiliki kemampuan regulasi emosi yang baik maka individu tersebut mampu berperilaku sesuai dengan harapan lingkungannya. Seperti yang diungkapkan oleh Silaen \& Dewi (2015) bahwa individu yang mampu meregulasi dirinya, maka individu tersebut akan dapat memahami dan mengetahui perilaku seperti apa yang dapat diterima oleh lingkungan.

\section{Pengaruh Self-Esteem Terhadap Penyesuaian Diri Akademik}

Berdasarkan hasil penelitian ini, ditemukan terdapat pengaruh regulasi emosi mempunyai pengaruh positif terhadap penyesuaian diri akademik pada mahasiswa, dimana variabel pada regulasi emosi mempunyai pengaruh sebesar $62,6 \%$. Artinya, semakin tinggi variabel selfesteem maka semakin tinggi penyesuaian diri akademik pada mahasiswa. Hasil ini sejalan dengan penelitian Permatasari \& Savira (2018) yang menunjukkan adanya hubungan positif dan signifikan yang cukup kuat antara Self-Esteem dan penyesuaian diri akademik mahasiswa. Dengan demikian, semakin tinggi Self-Esteem maka semakin tinggi pula penyesuaian diri akademik mahasiswa, begitupun sebaliknya jika self-esteem rendah maka penyesuaian diri juga akan rendah. Hasil penelitian ini juga didukung oleh Hernandez (2017) yang menyimpulkan bahwa terdapat hubungan yang signifikan antara self-esteem dengan penyesuaian diri di perkuliahan yang terdapat di Perguruan tinggi di Kota Calapan, Filipina, penelitian ini ditujukan kepada 357 mahasiswa tingkat pertama yang dipilih dari perguruan tinggi yang telah ditentukan. Hubungan antara kedua variabel tersebut memiliki hubungan yang positif.

Penyesuaian diri merupakan suatu proses kematangan individu dan perilaku manusia dalam menghadapi kebutuhan dengan lingkungan, sedangkan self-esteem merupakan evaluasi keseluruhan seseorang atas nilai dirinya, baik pada aspek fisik, psikologis, sosial maupun aspek akademik (Wijaya, 2012). Jika seseorang menilai dirinya positif, maka individu tersebut memiliki usaha yang lebih baik untuk mengatasi kebutuhan batin, ketegangan, konflik serta frustasi yang terdapat pada diri individu. Individu dengan harga diri tinggi akan lebih memiliki kemampuan untuk melakukan penyesuaian dibandingkan dengan individu yang memiliki harga diri yang rendah. Individu yang memiliki self-esteem tinggi memiliki karakteristik seperti lebih mampu mentoleransi kesulitan internal dan lebih mudah menyesuaikan diri dengan suasana yang menyenangkan sehingga tingkat kecemasannya rendah dan memiliki ketahanan diri yang seimbang maka dapat di katakan bahwa individu yang mampu menghargai diri sendiri memiliki karakteristik dapat menerima keadaan diri serta mampu menerima kritik dengan baik, sehingga berdasarkan hal tersebut individu yang menghargai dirinya sendiri juga dapat mengakui kegagalan yang dialami (Permatasari \& Savira, 2018). Hernandez (2017) menambahkan bahwa orang yang memiliki gagasan yang jelas mengenai apa yang mereka yakini dan apa yang mereka hargai akan cenderung lebih menyukai dan menghormati diri sendiri. Individu yang memiliki self-esteem yang baik juga merasa mampu mencapai suatu hasil yang diharapkan. Individu yang memiliki penyesuaian diri yang baik memiliki tujuan dan arah yang jelas, sehingga bertindak sesuai arahan, tujuan, dan usaha yang terorganisir.

Pengaruh Regulasi Emosi dan Self-Esteem Terhadap Penyesuaian Diri Akademik

Berdasarkan hasil penelitian ini, ditemukan terdapat pengaruh regulasi emosi mempunyai pengaruh positif terhadap penyesuaian diri akademik pada mahasiswa, dimana variabel pada 
regulasi emosi mempunyai pengaruh sebesar $69,3 \%$. Hasil penelitian ini selaras dengan pernyataan Sandha P et al., (2018) bahwa penyesuaian pada hakikatnya adalah usaha individu untuk berhasil mengatasi kebutuhan, ketegangan, konflik, dan frustrasi yang dialami di dalam dirinya, yang berasal dari dalam atau luar individu agar terjadi hubungan yang menyenangkan antara individu dengan lingkungannya. Terdapat beberapa ciri yang menunjukan individu dengan penyesuaian diri yang baik atau well-adjustment (Sundari, 2005). Berdasarkan hasil penelitian dari Sandha P et al., (2018) diketahui bahwa selfesteem adalah salah satu faktor yang mempengaruhi penyesuaian diri. Self-Esteem merupakan pendapat individu mengenai dirinya sendiri tentang rasa keberhargannya yang di ekspresikan dalam sikap penerimaan atau penolakan yang menujukkan sejauh mana individu percaya bahwa dirinya mampu, berarti, berhasil dan berharga (Sandha P et al., 2018). Self-esteem berperan sebagai jembatan untuk menanggulangi penyesuaian diri individu pada suatu lingkungan tertentu (Sari \& Rusli, 2019).

Mahasiswa mengalami pengalaman baru selama di perkuliahan namun tetap akan berhadapan pada stress atau permasalahan. Stres dan konflik yang rumit, serta proses pemecahan masalah mengambil sebagian besar penyesuaian diri pada kehidupan kampus (Rizki \& Listiara, 2015). Oleh karena penting bagi individu untuk dapat memfokuskan perhatian pada permasalahan serta mengarahkan tingkah laku yang sesuai dengan pemecahan masalah sehingga mampu mengatasi permasalahan yang ada agar dapat berhasil dalam menyesuaikan diri di kehidupan kampus dan juga sebagai persiapan untuk menghadapi kehidupan setelah lulus. Sandha P et al., (2018) menyatakan lima ciri penyesuaian diri positif, yaitu individu dapat memecahkan problem dengan menggunakan rasio dan emosi terkendali, tidak menggunakan mekanisme psikologis baik defense mechanism maupun escape mechanism dalam memecahkan problem, bersikap realistis dan objektif, serta belajar dari pengalaman sebagai pemecahan problem.

Penyesuaian diri dapat diperoleh melalui proses belajar memahami, mengerti dan berusaha melakukan apa yang diinginkan individu maupun lingkungannya. Individu yang mampu menyesuaikan diri dengan baik akan mampu mencari sisi positif, kreatif dalam mengelola kondisi serta mampu mengendalikan diri, sikap dan perilakunya. Kemampuan tersebut membuat individu akan lebih mudah diterima untuk lingkungannya, namun tidak semua dapat menyesuaikan diri dengan lingkungan, transisi tersebut menimbulkan konflik emosi khususnya bagi remaja atau usia muda yang muda mengalami depresi, kecemasan sampai bunuh diri atau mencoba bunuh diri (Sandha P et al., 2018). Gejala emosi yang lain adalah stres adalah suatu proses dalam rangka menilai suatu peristiwa sebagai suatu yang mengancam, menantang, atau membahayakan, serta individu merespon peristiwa itu baik pada level psikologis, emosional, kognitif, dan tingkah laku. Stres timbul karena transisi berlangsung pada suatu masa ketika banyak perubahan pada individu yaitu fisik, sosial, dan psikologis.

\section{Simpulan}

Berdasarkan hasil penelitian ini, maka dapat dibuat kesimpulan yaitu sebagai berikut : Adanya pengaruh regulasi emosi terhadap penyesuaian diri akademik mahasiswa, adanya pengaruh self-esteem terhadap penyesuaian diri akademik mahasiswa serta adanya pengaruh regulasi emosi dan self-esteem terhadap penyesuaian diri akademik mahasiswa.

Dengan demikian, maka penulis akan memberikan saran yang sekiranya dapat bermanfaat bagi pihak-pihak yang terlibat. Bagi mahasiswa diharapkan dapat mengembangkan kemampuan dalam penyesuaian diri dengan dengan meningkatkan regulasi emosi dan selfesteem, seperti dengan terlibat dalam diskusi yang aktif dalam perkuliahan, mengikuti kegiatan-kegiatan organisasi atau yang berhubungan dengan prestasi akademik, lebih aktif terlibat dalam mengikuti kegiatan yang dapat meningkatkan self-esteem. Bagi pihak lembaga pendidikan agar lebih memperhatikan faktor-faktor yang dapat mempengaruhi penyesuaian 
diri akademik pada mahasiswa, seperti kemampuan regulasi emosi dan self-esteem pada individu. Untuk meningkatkan penyesuaian diri akademik pada mahasiswa, pihak universitas dapat memberikan stimulus berupa berbagai kegiatan dan proses pembelajaran yang dapat menunjang serta meningkatkan kemampuan regulasi dan self-esteem pada mahasiswa, tetap memberikan apresiasi terhadap hasil kerja mahasiswa, serta memberikan peluang dan kesempatan bagi mahasiswa untuk tetap terlibat dalam proses perkuliahan secara baik. Hal ini diharapkan dapat memicu adanya peningkatan terhadap penyesuaian diri akademik pada mahasiswa. Pihak universitas juga perlu meningkatkan kondisi yang lebih kondusif sehingga mampu memberikan suasana perkuliahan yang nyaman dan berdampak positif pada penyesuaian diri akademik mahasiswa. Disamping itu, pengawasan terhadap mahasiswa juga perlu ditingkatkan agar pihak universitas dapat secara mudah mengetahui dan melakukan evaluasi terhadap permasalahan yang terjadi pada setiap mahasiswa, baik saat berada dalam universitas maupun diluar itu. Adapun penelitian ini tidak luput dari keterbatasan, salah satunya dalam penelitian ini ada beberapa mahasiswa yang tidak mengisi angket yang telah disebar sehingga penulis harus menghubungi mahasiswa untuk mengisi angket tersebut dan juga pada uji keterbacaan banyak hasil angket yang tidak valid karena dalam pengisianya dilakukan secara asal.

\section{Ucapan Terima Kasih}

Terima kasih diucapkan kepada Dosen pembimbing yang sudah mengarahkan, membimbing dan memberikan petunjuk, dan juga kepada pihak Program Studi Bimbingan dan Konseling, Jurusan Ilmu Pendidikan, Fakultas Keguruan dan Ilmu Pendidikan, Universitas Cenderawasih yang secara sukarela dan menjadi tempat pelaksanaan penelitian.

\section{Daftar Pustaka}

Anggraini, L. N. O., \& Desiningrum, D. R. (2018). Hubungan Antara Regulasi Emosi Dengan Intensi Agresivitas Verbal Instrumental Pada Suku Batak di Ikatan Mahasiswa Sumatera Utara Universitas Diponegoro. Empati, 7(3), 270-278.

Anggreiny, N., \& Sulistyaningsih, W. (2013). Rational Emotive Behavioural Therapy ( REBT) Untuk Meningkatkan Kemampuan Regulasi Emosi. 57-61. https://doi.org/10.31289/analitika.v5i2.786

Br Sembring, E., \& Lim, P. (2020). Edukasi Adaptasi Kebiasaan Baru di Lingkungan Kampus (Studi Kasus : Motion Graphic Penggunaan Lift). Journal Teknik Informatika, 3(2), 6176.

Fanani, Q., \& Jainurakhma, J. (2020). Kemampuan Penyesuaian Diri Mahasiswa Terhadap Pembelajaran Daring Di Tengah Pandemi Covid-19. Jurnal KomtekInfo, 7(4), 285-292. http://lppm.upiyptk.ac.id/ojsupi/index.php/KOMTEKINFO/article/view/1596/380

Fitri, R., \& Kustanti, E. R. (2018). Mahasiswa Rantau dari Indonesia Bagian Timur di Semarang. Empati, 7(April), 66-79.

Goleman, D. (2015). Emotional Intelligence,. Gramedia Pustaka Utama.

Gross, J. J., \& Jhon, O. P. (2003). Individual Differences In Two Emotion Regulation Processes: Implications for Affect, Relationships, and Well-Being. Journal of Personality and Social Psychology, 85(2), 348-362.

Khairat, M., \& Adiyanti, M. G. (2016). Self-Esteem dan Prestasi Akademik sebagai Prediktor Subjective Well-being Remaja Awal. Jurnal Psikologi UGM, 1(3), 180-191. https://doi.org/10.22146/gamajop.8815

Hernandez, R. R. M. (2017). Freshmen Students' Self-Esteem and Adjustment to College in 
Higher Education Institutions in Calapan City, Philippines. Asia Pacific Journal of Multidisciplinary Research, 5(3), 49-56.

Patawari, M. Y. (2020). Adaptasi Budaya pada Mahasiswa Pendatang di Kampus Universitas Padjadjaran Bandung. Jurnal Manajemen Komunikasi, 4(2), 103. https://doi.org/10.24198/jmk.v4i2.25900

Permatasari, R., A. \& Savira, S., I. (2018). Hubungan Antara Self-Esteem dengan Penyesuaian Diri Pada Mahasiswa Psikologi Angkatan 2017 Universitas Negeri Surabaya. Character: Jurnal Penelitian Psikologi., 5(2).

Rizki, M., \& Listiara, A. (2015). Penyesuaian Diri dan School Well-Being pada Mahasiswa. Seminar Psikologi \& Kemanusiaan, 978-979.

Sakinah, U. (2017). Identifikasi Faktor-Faktor Penyesuaian Akademik pada Mahasiswa Tahun Pertama Pendidikan Tata Boga UNIMED. SP - Psychology, 2-Oct-2017. http://repository.uma.ac.id/handle/123456789/8444

Sandha P, T., Hartati, S., \& Fauziah, N. (2018). Hubungan Antara Self Esteem dengan Penyesuaian Diri Pada Siswa Tahun Pertama SMA Krista Mitra Semarang. Jurnal Psikologi, 1(1), 47-82.

Saniskoro, B. S. R., \& Akmal, S. Z. (2017). Peranan Penyesuaian Diri di Perguruan Tinggi Terhadap Stres Akademik Pada Mahasiswa Perantau di Jakarta. Jurnal Psikologi Ulayat, 4(1), 96. https://doi.org/10.24854/jpu12017-82

Sari, A. P., \& Rusli, D. (2019). Pengaruh Self Esteem Terhadap Penyesuaian Diri Pada. Jurnal Riset Psikologi, 2019(1), 1-10. http://ejournal.unp.ac.id/students/index.php/psi/article /view/6195/3107

Schneider, A. A. (1964). Personal Adjustment and Mental Health. Holt, Rinehart and Winston Inc.

Silaen, A. C., \& Dewi, K. S. (2015). Hubungan Antara Regulasi Emosi dengan Asertivitas (Studi Korelasi Pada Siswa di SMA Negeri 9 Semarang). Empati, 4(2), 175-181.

Sugiyono. (2017). Metode Penelitian Kuantitatif Kualitatif dan $R \& D$. Bandung: Alfabeta.

Sundari, S. (2005). Kesehatan Mental dalam Kehidupan. Jakarta: Rineka Cipta.

Tarigan, V. A. (2018). Kondisi Resiliensi Mahasiswa Aktif Program Studi Bimbingan dan Konseling. 16, 50-62.

Widuri, E. L. (2012). Regulasi Emosi dan Resiliensi Pada Mahasiswa Tahun Pertama. $\begin{array}{lllll}\text { HUMANITAS: Indonesian Psychological Journal, } & 9(2), & 147 .\end{array}$ https://doi.org/10.26555/humanitas.v9i2.341

Wijaya, I. P., (2012). Efikasi Diri Akademik, Dukungan Sosial Orangtua dan Penyesuaian Diri Mahasiswa Dalam Perkuliahan. Persona:Jurnal Psikologi Indonesia, 1(1), 40-52. https://doi.org/10.30996/persona.v1i1.14

Yusuf, P., \& Kristiana, I. (2017). Hubungan Antara Regulasi Emosi Dengan Perilaku Prososial Pada Siswa Sekolah Menengah Atas. Empati: Jurnal Karya Ilmiah S1 Undip, 6(3), 98-104. 